\title{
Hubungan Antara Body Shaming Dan Citra Diri Dengan Kecemasan Sosial Pada Siswa SMP Ekasakti Semarang
}

\author{
Intan Ayu Setyarini, Eem Munawaroh \\ Bimbingan dan Konseling, Fakultas Ilmu Pendidikan, Universitas Negeri Semarang
}

\begin{abstract}
Abstrak
Ucapan verbal bisa membuat orang yang terkena body shaming menjadi down, malas dalam melakukan hal apapun, menangis, dan sedih. Peran guru serta orang tua sangat penting dalam hal memberikan dukungan kepada siswa yang menjadi korban body shaming dan perlu mendapat tindakan tegas dari sekolah yang bersangkutan.Populasi dalam penelitian ini adalah siswa kelas VIII SD kelas IX SMP Ekasakti Semarang, sebanyak 210 siswa perempuan. Metode pengumpulan data menggunakan kuisioner dengan instrumen skala likert yang terdiri empat pilihan. Hasil pengujian, terdapat hubungan positif dan signifikan antara body shaming dengan kecemasan sosial, sehingga semakin tinggi body shaming maka akan semakin tinggi kecemasan sosialnya, sebaliknya semakin rendah body shaming, maka akan semakin rendah kecemasan sosialnya, kedua variabel tersebut berkorelasi kuat, artinya semakin tinggi citra diri siswa akan semakin rendah kecemasan sosialnya, sebaliknya semakin rendah citra diri siswa akan semakin tinggi kecemasan sosialnya, maka kedua variabel tersebut memiliki korelasi yang kuat.
\end{abstract}

kata kunci: body shaming, self image, social anxiety

\begin{abstract}
Verbal speech can make people affected by body shaming become down, lazy to do anything, cry, and become sad. The role of teachers and parents is very important in terms of providing support to students who are victims of body shaming and need to take firm action from the school concerned. The population in this study were students of class VIII SD class IX SMP Ekasakti Semarang, totaling 210 female students. The data collection method used a questionnaire with a Likert scale instrument consisting of four options. The test results show that there is a positive and significant relationship between body shaming and social anxiety, so the higher the body shaming, the higher the social anxiety, conversely the lower the body shaming, the lower the social anxiety, the two variables are strongly correlated, meaning that the higher the image. The students themselves will have lower social anxiety, on the other hand, the lower their self-image, the higher their social anxiety, so the two variables have strong correlation.
\end{abstract}

Keywords: body shaming, self image, social anxiety 


\section{PENDAHULUAN}

Dampak body shaming paling lebih banyak yang negatif dan cenderung untuk mengikuti perkataan orang lain terkait dengan kondisi tubuh seseorang. Contoh misalnya malu terhadap bentuk tubuhnya, tidak nafsu makan, tidak percaya diri, tidak layak dalam kelompok sosial, depresi, bahkan bisa melakukan bunuh diri. Akan tetapi body shaming juga dapat memberikan dampak positif bagi seseorang, yaitu lebih cuek terhadap perkataan orang tentang bentuk tubuhnya, meningkatkan percaya diri, menjadi seseorang yang cinta pada dirinya, serta memberikan bukti bahwa bisa berubah lebih baik. Terdapat 966 kasus penghinaan fisik atau body shaming yang ditangani polisi dari seluruh Indonesia sepanjang 2018. Sebanyak 347 kasus di antaranya selesai, baik melalui penegakan hukum maupun pendekatan mediasi antara korban dan pelaku, ada juga kasus Siswi SMP 147 bunuh diri di sekolah, KPAI: Hampir semua sekolah tak punya tim pencegahan perundungan, siswi berinisial $\mathrm{N}$ lompat dari gedung lantai 4 sekolahnya disebabkan karena sering diejek oleh temannya.

Body shame mediated the association between materialism and body dissatisfaction (Sun, 2018). - Rasa malu tubuh memediasi hubungan antara materialisme dan ketidakpuasan tubuh. Akibat dari ketidakpuasan tubuh adalah dengan mengubah pola makan menjadi lebih sedikit kuantitasnya. Hal ini akan berpengaruh pada kesehatan dan konsumsi gizi harian tubuh. Body shaming juga pernah dialami oleh beberapa artis perempuan, contohnya Tara Basro dan Prilly Latuconsina. Mengutip dari laman kompas.com, Tara Basro menggunggah foto dirinya yang terbuka dengan memperlihatkan tubuh berisi dan menuliskan keterangan "Worthy of Love". Tara juga menambahkan, "Coba percaya sama diri sendiri". Dari unggahan tersebut menuai pro dan kontra karena dianggap melanggar UU ITE, akan tetapi banyak warganet mendukungnya. Lalu pada kasus Prilly Latuconsina dengan mengutip dari laman kompas.com Prilly kehilangan nafsu makan akibat dari perkataan orang yang mengatakan dirinya jika dilihat di TV gemuk dan jika bertemu secara langsung tidak gemuk. Prilly merasa kesal sehingga membuat dirinya kelaparan dan menyebabkan asam lambung.

Kecemasan sosial adalah salah satu jenis dari gangguan kecemasan yang bersifat spesial, dimana kita merasakan pengalaman yang tidak nyaman ketika berada di sekitar banyak orang dan merasa khawatir dengan apa yang orang lain pikirkan tentang kita. Kecemasan sosial bukanlah sesuatu yang dapat diukur dari sekedar mengamati. Ketidakpuasan terhadap bentuk tubuh lebih banyak dialami oleh remaja perempuan dibandingkan dengan remaja laki-laki. Remaja perempuan lebih kurang puas dengan keadaan tubuhnya dan memiliki lebih banyak gambaran tubuh negatif (Ratnasari, 2017). Hal tersebut disebabkan pada saat mulai memasuki masa remaja, seorang perempuan akan mengalami peningkatan lemak tubuh yang membuat tubuhnya semakin jauh dari bentuk tubuh yang ideal. Untuk itu remaja perempuan takut dibully oleh lingkungan sekitarnya, sehingga melakukan usaha seperti diet, perawatan tubuh, olahraga agar memiliki tubuh ideal yang langsing.

Berdasarkan hasil survey bagi remaja perempuan mulai merasa tak puas dengan bentuk tubuhnya pada usia 16 tahun, sehingga remaja kurang percaya diri karena kurang puas dengan tubuhnya. Body Image terbentuk dari faktor internal seperti bagaimana seseorang melihat, merasakan, dan percaya pada diri terhadap keadaan diri sendiri. Penelitian yang dilakukan oleh Aprianty pada remaja awal di SMPN 1 Jatinangor yang mengalami kecemasan sosial yang tinggi sebanyak $22.9 \%$. Prabundari mengatakan bahwa majalah membuat banyak perempuan menginternalisasi dan menerima budaya "kurus ideal" dan memotivasi mereka untuk mendapatkan tubuh yang ideal. Oleh karena itu, memiliki tubuh yang ramping dipersepsikan di mana pun sebagai salah satu hal penting yang menentukan kebahagiaan seorang perempuan.

Body shaming menimbulkan kecemasan terhadap individu. Body shaming yang terjadi menyebabkan individu rentan pada gangguan dismorfik tubuh (Body Dismorphic Disorder/BDD) (Dolezal, 2015). Gangguan dismorfik tubuh menyebabkan individu merasa bahwa ada yang kurang pada dirinya. Cash mengemukakan ada lima aspek dalam pengukuran body image, yaitu: evaluasi penampilan, orientasi penampilan, kepuasan terhadap bagian tubuh, kecemasan menjadi gemuk, pengkategorian ukuran tubuh. Individu yang peduli akan penampilanya akan selalu melakukan evaluasi dengan penampilannya, dan tidak akan merasa cemas apabila tubuhnya menjadi gemuk atau kekurusan. Dari hal tersebut individu akan belajar menerima kekurangan dan kelebihan dirinya sehingga individu tersebut akan lebih percaya diri. 
Citra diri di sebut juga dengan gambaran diri, citra diri adalah sikap seseorang terhadap tubuhnya secara sadar dan tidak sadar. Sikap ini mencakup persepsi dan perasaan tentang ukuran, bentuk, fungsi penampilan dan potensi tubuh saat ini dan masa lalu yang secara berkesinambungan di modifikasi dengan pengalaman baru setiap individu (Hidayat et al., 2019). Citra tubuh memengaruhi penerimaan diri seseorang terhadap lingkungannya, sehingga semakin tinggi citra tubuh, maka semakin tinggi pula penerimaan diri seseorang terhadap dirinya (Sakinah, 2018). Adanya citra tubuh memungkinkan seseorang untuk membandingkan keadaan dirinya dengan orang lain dan menimbulkan rasa malu terhadap tubuh, yang sering disebut dengan istilah body shaming. Body shaming merupakan penilaian individu akan tubuhnya yang memunculkan perasaan bahwa tubuhnya memalukan yang disebabkan penilaian dirinya dan orang lain terhadap bentuk tubuh ideal tidak sesuai dengan tubuhnya (Damanik 2018).

Citra tubuh berkaitan dengan body shaming. Kajian Damanik (2018) yang berfokus pada dinamika psikologis perempuan yang mengalami body shaming pada perempuan usia dewasa awal dan menunjukkan bahwa mereka yang mengalami body shaming akan lebih memperhatikan tubuh dan dijadikan sebagai objek (self-objectification). Hal ini menyebabkan rasa cemas dan meningkatkan rasa malu terhadap diri sendiri. Mereka melakukan usaha untuk mengurangi rasa malu yang membuat mereka menjadi objek body shaming. Ini disebabkan oleh citra tubuh berhubungan dengan persepsi seseorang, perasaan dan pikirannya tentang dirinya atau tubuhnya dan biasanya memiliki tubuh yang dinilai dari penilaian ukuran, ulasan daya tarik tubuh dan emosi yang terkait dengan bentuk tubuh dan ukurannya.

Surya (2009) menyatakan bahwa seorang akan percaya diri ketika orang tersebut menyadari bentuk tubuhnya yang sangat ideal dan orang tersebut merasa puas melihat bentuk tubuhnya, maka body image yang terbentuk pun menjadi positif. Sebaliknya, jika seseorang memandang tubuhnya tidak ideal seperti wajahnya kurang menarik, badannya terlalu gemuk atau terlalu kurus dan sebagainya, maka orang tersebut menjadi sibuk memikirkan kondisi fisiknya, sehingga body image yang terbentuk menjadi negatif dan dapat dikatakan orang tersebut tidak memiliki kepercayaan diri. Temuan yang dilakukan oleh Neumark bersama rekannya di tahun 2004 dalam jurnal Weight-control behaviors among adolescent girls and boys: Implications for dietary intake menunjukkan bahwa wanita lebih sering mengalami ketidakpuasan akan bentuk tubuh, hal utama yang menjadi momok yang menakutkan sebagian orang terutama wanita adalah kegemukan. Penelitian tersebut pun diperkuat dengan adanya propoganda media yang sangat signifikan meningkatkan citra tubuh wanita menjadi negatif, temuan pada meta-analisis yang dilakukan Grabe dan Ward di tahun 2008 mendukung anggapan paparan gambar media yang menggambarkan tubuh kurus sangat ideal berkaitan dengan gambaran tubuh wanita (Wiranatha \& Supriyadi, 2015).

Berbagai penelitian terdahulu mengenai citra tubuh memberikan hasil bahwa citra tubuh berkorelasi dengan berbagai aspek psikologis. Semakin tinggi citra tubuh positif individu maka akan semakin baik pula aspek psikologis lainnya, sedangkan semakin buruk citra tubuh individu maka akan semakin negatif pula aspek psikologis lainnya. Penelitian yang dilakukan oleh Sri Adiningsih pada tahun 2008 di Surabaya memberikan hasil bahwa citra tubuh berkorelasi positif terhadap perilaku makan remaja. Semakin negatif citra tubuh remaja, maka pola makan remaja semakin buruk dan cenderung melakukan berbagai diet. Penelitian lain,dilakukan oleh Lia Rohliyani pada tahun 2011 tentang hubungan antara citra tubuh dan perilaku konsumtif remaja kelas XI di SMA Negeri 24 Bandung memberikan kesimpulan bahwa remaja yang memiliki citra tubuh yang negatif akan semakin banyak menghabiskan uang untuk perawatan demi memperoleh bentuk tubuh yang diinginkan dan lebih banyak membeli barang-barang yang sebenarnya tidak begitu diperlukan hanya untuk memperoleh pengakuan dari teman sebaya nyasebagai cara untuk menutupi kekurangannya secara fisik.

Studi deskriptif kualitatif yang dilakukan oleh Aulia Karima pada tahun 2013 mengenai citra tubuh pada remaja cover dance di Kota Bandung memberikan hasil bahwa remaja yang merasa dirinya tidak menarik secara fisik merasa tidak percaya diri dan minder ketika menari daripada remaja cover dance yang merasa dirinya cukup menarik secara fisik. Sedangkan penelitian yang dilakukan di luar negeri salah satunya oleh Levine \& Smolak yang menjelaskan bahwa 40-70\% remaja putri di Amerika berusia antara 12-17 tahun merasa tidak puas dengan dua anggota tubuh mereka atau lebih, sedangkan di berbagai negara berkembang antara 50-80\% remaja putri mendambakan tubuh yang lebih kurus dan hampir 20-60\% diantaranya melakukan berbagai macam diet demi memperoleh bentuk tubuh yang mereka inginkan.

Menurut Papalia, Olds \& Feldman (2009) dan Santrock (2011), perhatian utama terkait citra tubuh 
dapat ditemukan pada masa kanak-kanak tengah (usia sekolah dasar), terutama pada anak perempuan, yang mengakibatkan pada gangguan makan di masa remajanya. Salah satu penyebabnya diduga adalah karena anak perempuan lebih banyak bermain boneka yang bentuk tubuhnya tidak realistic. Sedangkan pada masa remaja, remaja dianggap sangat memperhatikan penampilan dan tubuhnya disebabkan karena faktor pubertas. Pada masa ini, seringkali perbedaan gender mewarnai kepuasan dan ketidakpuasan remaja terhadap tubuhnya. Dari hasil penelitian Bearman dkk (dalam Santrock, 2011) ditemukan bahwa remaja perempuan cenderung lebih tidak puas terhadap tubuhnya yang mungkin disebabkan oleh peningkatan lemak tubuh dalam perkembangan fisiknya.

Body shaming sering terjadi di SMP Ekasakti Semarang. Hal tersebut dilakukan tidak hanya oleh siswa laki-laki, tetapi perempuan juga melakukannya. Body shaming tersebut dilakukan secara verbal, dengan menyebutkan kata-kata seperti dasar gendut, hidung jambu atau pesek, putihan dikit napa, buluk banget dan sebagainya. Terkadang ucapan verbal tersebut bisa membuat orang yang terkena body shaming menjadi down, malas dalam melakukan hal apapun, menangis, dan sedih. Peran guru serta orang tua memanglah sangat penting dalam hal memberikan dukungan kepada siswa yang menjadi korban body shaming dan perlu mendapat tindakan tegas dari instansi sekolah yang bersangkutan.

Berdasarkan uraian latar belakang diatas penulis tertarik melakukan penelitian tentang body shaming dengan judul "Hubungan Antara Body Shaming dan Citra Diri dengan Kecemasan Sosial Pada Siswa SMP Ekasakti Semarang". Tujuan dari penelitian ini adalah untuk mengetahui hubungan perlakuan body shaming dan citra diri dengan kecemasan sosial pada siswa SMP Ekasakti Semarang.

\section{METODE PENELITIAN}

Penelitian ini menggunakan pendekatan kuantitatif, yaitu pendekatan yang digunakan untuk meneliti variabel dengan berorientasi pada proses pengukuran (Saifuddin, 2020). Metode dalam penelitian ini adalah metode penelitian kuantitatif korelasional, dimana bertujuan untuk menyelidiki sejauh mana variasi pada suatu variabel berkaitan dengan variasi pada satu atau lebih variabel lain.

Teknik pengumpulan data yang digu- nakan adalah: obsevasi, kuisioner, dan dokumentasi. Penetian ini dilaksanakan di SMP Ekasakti Semarang, Jl. Kr. Rejo Raya No.64, Srondol Wetan, Kec. Banyumanik, Kota Semarang, Jawa Tengah 50263. Populasi dalam penelitian ini adalah siswa kelas VIII sd kelas IX SMP Ekasakti Semarang, sebanyak 210 siswa perempuan saja. Sampel yang didapatkan sebanyak 138 siswa diambil dari kelas VIII s.d. kelas IX. Analisis Instrumen Penelitian, Analisis Reliabilitas, Validitas. Analisis data hasil penelitian, menggunakan uji normalitas, uji linieritas.

\section{HASIL}

Penelitian mengenai hubungan antara body shaming dan citra diri dengan kecemasan sosial pada siswa putri dilakukan di di SMP Ekasakti Kota Semarang. Langkah awal yang harus dilakukan sebelum melakukan penelitian adalah menentukan tempat atau kancah penelitian dan memberikan gambaran singkat yang menyeluruh mengenai situasi yang merupakan ciri khas dari kancah penelitian. Dalam menentukan kancah penelitian, penulis mengadakan pengamatan pendahuluan terhadap kancah penelitian dan ciri-ciri populasi yang telah ditetapkan oleh penelitian.

Alasan menggunakan SMP Ekasakti sebagai kancah penelitian adalah berdasarkan observasi peneliti saat praktek di sekolah ini dan diperkuat data dari guru BK yang menyatakan bahwa sering terjadi body shaming yang dilakukan oleh para siswa di sekolah tersebut, terutama pada siswa perempuan.

Persiapan yang dilakukan sebelum melakukan penelitian diantaranya adalah: Persiapan administratif dalam penelitian ini meliputi perijinan dan surat menyurat. Sesuai dengan prosedur yang berlaku maka surat perijinan penelitian perlu mendapatkan rekomendasi dari Fakultas Ilmu Kependidikan UNNES yang disampaikan kepada sekolah SMP Ekasakti. Pengambilan data dilakukan pada tanggal buan November 2020.

Persiapan Instrumen Penelitian Instrumen yang digunakan dalam penelitian ini berupa skala psikologis dan angket. Sebelum melakukan penelitian instrumen yang akan digunakan diuji konstruk terlebih dahulu, yaitu uji validitas oleh ahli. Setelah melalui validitas konstruk maka uji instrumen dilanjutkan dengan uji coba terhadap responden dengan karakteristik yang sama dengan populasi. 
Uji coba instrumen penelitian dilakukan pada tanggal 12 November 2020 di SMP Ekasakti dengan jumlah responden sebanyak 30 siswa perempuan yang tergabung dalam satu kelas. Uji coba dilakukan dikelas tersebut karena populasi di kelas tersebut tidak termasuk kedalam sampel penelitian.

Instrumen yang diuji-cobakan berjumlah 50 item pernyataan untuk variabel kecemasan sosial (Y), 40 pernyataan untuk variabel bpdy shaming (X1), dan 20 pernyataan untuk variabel citra diri (X2). Penelitian ini menggunakan angket dan skala tertutuk menggunakan model skala linkert berdasarkan indikatorindikator yang ada. Terdapat lima pilihan jawaban dalam angket yaitu SS (sangat sesuai), S (sesuai), N (Netral)m TS (tidak sesuai, dan STS (sangat tidak sesuai). Dimana pilihan jawaban akan diberi skala nilai: $5,4,3,2,1$ untuk jawaban yang favorable dan skala nilai: 1, 2, 3, 4,5 untuk jawaban yang unfavorable. Hasil uji coba instrumen dianalisis untuk mengetahui validitas dan reliabilitasnya. Analisis dilakukan menggunakan software SPSS.

Perhitungan uji validitas instrumen dilakukan menggnakan rumus korelasi product moment. Ketentuan validitas instrumen diukur berdasarkan kriteria validitas menurut Riduwan (2012) yang menyatakan bahwa sebuah item dalam instrumen dikatakan valid apabila $r_{\text {hitung }} \geq r_{\text {tabel }}$. Dalam penelitian ini diketahui nilai $r_{\text {tabel }}$ dengan taraf signiikasi $5 \%$ dan $\mathrm{n}=30$ adalah 0,361 .

Dari 50 item pernyataan pada variabel kecemasan sosial yang diajukan kepada 30 responden, terdapat lima item yang tidak valid yaitu item nomor 8, 13, 26, 31 dan 39 karena $r$ hitung $<\mathrm{r}$ tabel sehingga terdapat 45 item pernyataan yang dinyatakan valid karena $r$ hitung $>r$ tabel dengan nilai koefisien validitas terendah 0,368 dan tertinggi 0,708; maka 45 item yang valid tersebut dapat digunakan sebagai kuesioner penelitian variabel kecemasan sosial.

Dari 40 item pernyataan pada variabel body shaming yang diajukan kepada 30 responden, terdapat empat item yang tidak valid yaitu item nomor 12, 15, 29 dan 37 karena $r$ hitung $<\mathrm{r}$ tabel sehingga terdapat 36 item pernyataan yang dinyatakan valid karena $\mathrm{r}$ hitung $>\mathrm{r}$ tabel dengan nilai koefisien validitas terendah 0,386 dan tertinggi 0,729 ; maka 36 item yang valid tersebut dapat digunakan sebagai kuesioner penelitian variabel body shaming.

Dari 20 item pernyataan pada variabel citra diri yang diajukan kepada 30 responden, terdapat satu item yang tidak valid yaitu item nomor 18 karena $r$ hitung $<\mathrm{r}$ tabel sehingga terdapat 19 item pernyataan yang dinyatakan valid karena $r$ hitung $>r$ tabel dengan nilai koefisien validitas terendah 0,459 dan tertinggi 0,790; maka 19 item yang valid tersebut dapat digunakan sebagai kuesioner penelitian variabel kecemasan sosial.

Reliabilitas menunjukkan pengertian bahwa suatu instrumen cukup dapat dipercaya untuk dapat dipergunakan sebagai alat pengumpul data karena instrumen sudah cukup baik (Suharsimi, 2006). Realibilitas instrumen dari penelitian ini dihitung dengan bantuan komputer SPSS menggunakan uji statistik Cronbach Alpha untuk mengetahui apakah data penelitian ini reliabel atau tidak. Suatu konstruk atau variabel dikatakan reliabel jika memberikan nilai Cronbach Alpha > 0,70 (Ghozali, 2011).

Tabel

Hasil Perhitungan Uji Reliabilitas

\begin{tabular}{|l|l|l|l|l|}
\hline No. & Variabel & Cronbach's Alpha & $\begin{array}{l}\text { Minimal Cronbach's } \\
\text { Alpha }\end{array}$ & Keterangan \\
\hline 1 & Kecemasan Sosial & 0,945 & $>0,700$ & Reliabel \\
\hline 2 & Body Shaming & 0,939 & $>0,700$ & Reliabel \\
\hline 3 & Citra Diri & 0,920 & $>0,700$ & Reliabel \\
\hline
\end{tabular}

Sumber : Data primer yang diolah, 2020

Berdasarkan data yang ada dalam tabel di atas, dapat dilihat bahwa semua variabel penelitian memiliki nilai koefesiensi reliabilitas yang lebih tinggi daripada Cronbanch Alpha yang di syaratkan yaitu sebesar 0,700. Oleh karena itu dapat disimpulkan bahwa hasil instrumen ini memiliki tingkat reliabilitas yang tinggi, atau dapat dikatakan hasil instrumen ini dapat dipercaya.

Dalam pelaksanaannya penelitian ini menggunakan 138 responden berdasarkan hasil perhitungan dari 210 populasi yang ada. Pemilihan sampel atau responden dilakukan secara acak berdasarkan cluster (jenjang kelas) yang ada di sekolah yaitu kelas VII sebanyak 85 siswa, kelas VIII sebanyak 57 siswa dan 
kelas IX sebanyak 68 siswa.

Pengumpulan data dilakukan pada tanggal 15 November 2020 hingga tanggal 25 November 2020 melalui Google Form yang berisikan skala kecemasan sosial terdiri dari 45 butir item pernyataan, angket body shaming yang terdiri dari 36 butir item pernyataan dan skala citra didi yang terdiri dari 19 butir item pernyataan. Pengumpulan data dibantu oleh guru BK SMP Ekasakti Semarang yang memberikan akses berupa group chat kelas-kelas yang dijadikan sampel penelitian. Data yang diperoleh dalam pengumpulan ini adalah 138 data responden yang terdiri dari tiga kelas yang berbeda.

Setelah data terkumpul maka selanjutnya dilakukan skoring berdasarkan jenis item. Untuk item unfavorable diberikan skor 5 untuk pilihan jawaban SS (sangat setuju), skor 4 untuk pilihan jawaban S (setuju), skor 3 untuk pilihan jawaban N (netral), skor 2 untuk pilihan jawaban TS (tidak setuju) dan skor 1 untuk jawaban STS (sangat tidak setuju). Sedangkan untuk item favorable diberikan skor 1 untuk pilihan jawaban SS (sangat setuju), skor 2 untuk pilihan jawaban S (setuju), skor 3 untuk pilihan jawaban N (netral), skor 4 untuk pilihan jawaban TS (tidak setuju) dan skor 5 untuk pilihan jawaban STS (sangat tidak setuju). Setelah seluruh item diskoring kemudian dijumlahkan untuk masing-masing responden kemudian digunakan dalam analisis data.

Analisis deskriptif dilakukan untuk mengetahui karakteristik data dari setiap variabel penelitian. Hasil statistik deskriptif menunjukkan kategorisasi dari setiap variabel yaitu kecemasan sosial, body shaming dan citra diri. Kategorisasi tersebut kemudian akan dibagi menjadi lima golongan; sangat rendah, rendah, sedang, tinggi dan sangat tinggi. Hasil kategorisasi variabel kecemasan sosial adalah sebagai berikut :

Tabel

Deskriptif Variabel Kecemasan Sosial

\begin{tabular}{|l|l|l|l|l|}
\hline No & Rentang Nilai & Ketegori & Frekuensi & Persentase \\
\hline 1 & $20<\mathrm{N} \leq 36$ & Sangat Rendah & - & - \\
\hline 2 & $36<\mathrm{N} \leq 52$ & Rendah & 4 & $2,9 \%$ \\
\hline 3 & $52<\mathrm{N} \leq 68$ & Sedang & 102 & $73,9 \%$ \\
\hline 4 & $68<\mathrm{N} \leq 84$ & Tinggi & 32 & $23,2 \%$ \\
\hline 5 & $84<\mathrm{N} \leq 100$ & Sangat Tinggi & - & - \\
\hline Jumlah & 138 & $100,0 \%$ \\
\hline Nilai Minimum & 46,1 & \\
\hline Nilai Maksimum & 79,1 & \\
\hline Rerata & 64,15 \\
\hline Kriteria & Sedang \\
\hline
\end{tabular}

Gambar

Diagram Variabel Kecemasan Sosial

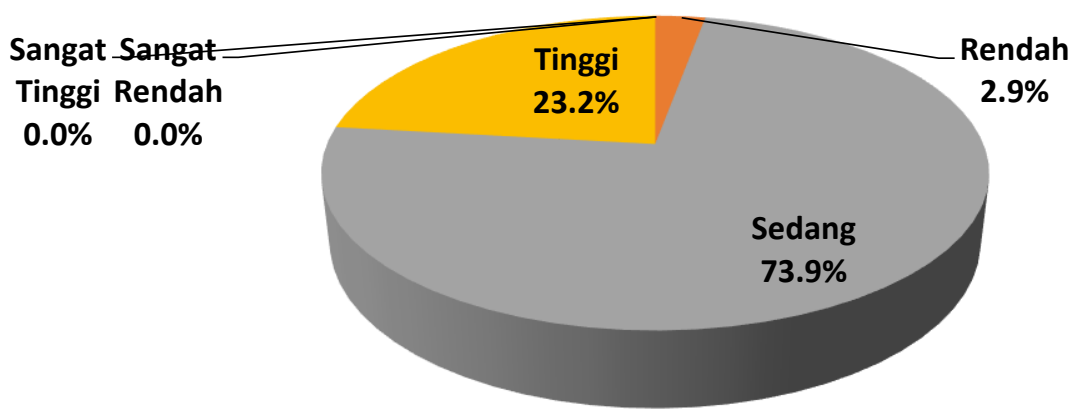

Berdasarkan kategori kecemasan sosial dapat dilihat bahwa rata-rata sampel dalam penelitian ini memiliki tingkat kecemasan sosial yang tergolong sedang dengan nilai rata-rata sebesar 64,15 . Sedangkan 
dilihat dari persentase respondennya dari total responden sebanyak 138 siswa diketahui responden yang memiliki kecemasan sosial tergolong sedang sebanyak 73,3\% dan yang memiliki kecemasan sosial tinggi sebanyak $23,2 \%$ serta diketahui sebanyak 2,9\% lainnya memiliki kecemasan sosial rendah. Maka dapat diartikan bahwa kecemasan sosial didominasi oleh kategori yang sedang, ketimbang mengalami kecamsan sosial yang tinggi atau bahkan kecemasan rendah.

Hasil kategorisasi variabel body shaming adalah sebagai berikut :

Tabel

Deskriptif Variabel Body Shaming

\begin{tabular}{|l|l|l|l|l|}
\hline No & Rentang Nilai & Ketegori & Frekuensi & Persentase \\
\hline 1 & $20<\mathrm{N} \leq 36$ & Sangat Rendah & - & - \\
\hline 2 & $36<\mathrm{N} \leq 52$ & Rendah & 8 & $5,8 \%$ \\
\hline 3 & $52<\mathrm{N} \leq 68$ & Sedang & 79 & $57,2 \%$ \\
\hline 4 & $68<\mathrm{N} \leq 84$ & Tinggi & 45 & $32,6 \%$ \\
\hline 5 & Sangat Tinggi & 6 & $4,3 \%$ \\
\hline Jumlah & $84<\mathrm{N} \leq 100$ & 138 & $100,0 \%$ \\
\hline Nilai Minimum & 41,1 & \\
\hline Nilai Maksimum & 95,0 & \\
\hline Rerata & 66,30 \\
\hline Kriteria & Sedang \\
\hline
\end{tabular}

Gambar

Diagram Variabel Body Shaming

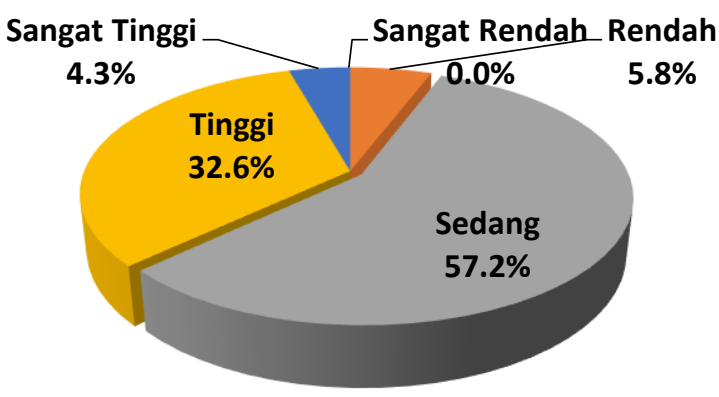

Berdasarkan kategori body shaming dapat dilihat bahwa rata-rata sampel dalam penelitian ini merasakan tingkat body shaming yang tergolong sedang dengan nilai rata-rata sebesar 66,30. Sedangkan dilihat dari persentase respondennya dari total responden sebanyak 138 siswa diketahui responden yang merasakan body shaming yang tergolong sedang sebanyak $57,2 \%$ dan yang merasakan body shaming tinggi sebanyak 32,6\% ; sebanyak 5,8\% merasakan body shaming rendah, serta diketahui sebanyak 4,3\% lainnya merasakan body shaming sangat tinggi. Maka dapat diartikan bahwa body shaming didominasi oleh kategori yang sedang, ketimbang mengalami body shaming yang tinggi atau bahkan body shaming rendah Hasil kategorisasi variabel citra diri adalah sebagai berikut :

Tabel

Deskriptif Variabel Citra Diri

\begin{tabular}{|l|l|l|l|l|}
\hline No & Rentang Nilai & Ketegori & Frekuensi & Persentase \\
\hline 1 & $20<\mathrm{N} \leq 36$ & Sangat Rendah & 8 & $5,8 \%$ \\
\hline 2 & $36<\mathrm{N} \leq 52$ & Rendah & 48 & $34,8 \%$ \\
\hline 3 & $52<\mathrm{N} \leq 68$ & Sedang & 75 & $54,3 \%$ \\
\hline 4 & $68<\mathrm{N} \leq 84$ & Tinggi & 6 & $4,3 \%$ \\
\hline 5 & $84<\mathrm{N} \leq 100$ & Sangat Tinggi & 1 & $0,7 \%$ \\
\hline Jumlah & & 138 & $100,0 \%$ \\
\hline
\end{tabular}




\begin{tabular}{|l|l|}
\hline Nilai Minimum & 24,2 \\
\hline Nilai Maksimum & 88,4 \\
\hline Rerata & 53,04 \\
\hline Kriteria & Sedang \\
\hline
\end{tabular}

\section{Gambar}

\section{Diagram Variabel Citra Diri}

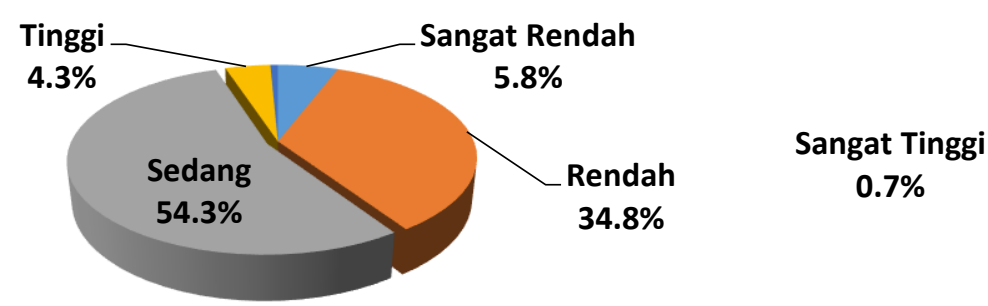

Berdasarkan kategori citra diri dapat dilihat bahwa rata-rata sampel dalam penelitian ini memiliki citra diri yang tergolong sedang dengan nilai rata-rata sebesar 53,04 Sedangkan dilihat dari persentase respondennya dari total responden sebanyak 138 siswa diketahui responden yang memiliki citra diri yang tergolong sedang sebanyak 54,3\% dan yang memiliki citra diri rendah sebanyak 34,\%; responden yang memiliki citra diri sangat rendah sebanyak 5,8\%; responden yang memiliki citra diri tinggi sebanyak 4,3\% serta diketahui sebanyak 0,7\% lainnya memiliki citra diri sangat tinggi. Maka dapat diartikan ternyata citra diri sedang mendominasi kemudian disusul citra diri rendah.

Melalui teknik analisis regresi ganda akan diperoleh nilai $R^{2}$ (R square) yang menunjukkan besarnya pengaruh variabel independen secara simultan terhdap variabel dependen.

Tabel

\section{Hasil Analisis Regresi Berganda}

\begin{tabular}{|l|l|l|l|l|}
\hline Model & R & R Square & Adjusted R Square & $\begin{array}{l}\text { Std. Error of the } \\
\text { Estimate }\end{array}$ \\
\hline 1 & $0,728(\mathrm{a})$ & 0,529 & 0,523 & 4,8073 \\
\hline
\end{tabular}

a Predictors: (Constant), Citra Diri (X2), Body Shaming (X1)

Berdasarkan hasil analisis diketahui nilai $\mathrm{R}$ square sebesar 0,529. Untuk mengetahui berapa peresentase pengaruh variabel independen secara simultan terhadap variabel dependen angka tersebut harus dikalikan 100\% sehingga besarnya pengaruh body shaming dan citra diri secara simultan terhadap kecemasan sosial sebesar 52,9\%. Hal ini berarti terdapat 47,1\% faktor lain yang mempengaruhi kecemasan sosial sebagai variabel dependen.

Sedangkan presentase pengaruh masing-masing variabel independen secara parsial terhadap variabel dependen (sumbangan efektif) diperoleh dari hasil perhitungan manual berdasarkan hasil koefisien regresi beta dan koefisien korelasi.

Sumbangan efektif (SE) body shaming terhadap kecemasan sosial pada siswa perempuan SMP Ekasakti Semarang sebesar 28,9\% lebih besar dibandingkan dengan pengaruh citra diri terhadap kecemasan sosial sebesar $24,0 \%$. Sumbangan relatif (SR) pengaruh body shaming dan citra diri terhadap kecemasan sosial pada siswa perempuan SMP Ekasakti Semarang dapat dilihat pada tabel berikut:

Diketahui besarnya sumbangan relatif body shaming terhadap kecemasan sosial pada siswa perempuan SMP Ekasakti Semarang sebesar 54,6\% lebih besar dibandingkan dengan pengaruh citra diri terhadap kecemasan sosial sebesar $45,4 \%$. Jadi dapat diambil kesimpulan bahwa body shaming memiliki pengaruh yang dominan terhadap kecemasan sosial.

\section{PEMBAHASAN}

Berdasarkan hasil penelitian diperoleh data kecemasan sosial siswa perempuan SMP Ekasakti 
Semarang terbagi dalam lima kategori, yaitu dari 138 siswa sebagai sampel penelitian diketahui responden yang memiliki kecemasan sosial tergolong sedang sebanyak 102 siswa yang memiliki kecemasan sosial tinggi sebanyak 32 siswa serta diketahui sebanyak 4 siswa lainnya memiliki kecemasan sosial rendah. Secara keseluruhan kecemasan sosial siswa perempuan SMP Ekasakti Semarang tergolong sedang dengan nilai rata-rata sebesar 102 orang responden.

Berdasarkan hasil penelitian menunjukkan bahwa responden yang merasakan body shaming yang tergolong sedang sebanyak 79 siswa dan yang merasakan body shaming tinggi sebanyak 45 siswa; sebanyak 8 siswa merasakan body shaming rendah, serta diketahui sebanyak 6 siswa lainnya merasakan body shaming sangat tinggi. Secara keseluruhan body shaming yang dirasakan siswa perempuan SMP Ekasakti Semarang tergolong sedang dengan nilai rata-rata sebesar 79 orang responden.

Hasil penelitian menunjukkan bahwa responden yang memiliki citra diri yang tergolong sedang sebanyak citra diri yang tergolong sedang sebanyak 75 siswa dan yang memiliki citra diri rendah sebanyak 48 siswa responden yang memiliki citra diri sangat rendah sebanyak 8 siswa responden yang memiliki citra diri tinggi sebanyak 6 siswa serta diketahui sebanyak 6 siswa lainnya memiliki citra diri sangat tinggi. Secara keseluruhan citra diri siswa perempuan SMP Ekasakti Semarang tergolong sedang dengan nilai rata-rata sebesar 53,04. Jadi ketiga variabel penelitian yaitu kecemasan sosial, body shaming dan citra diri siswa perempuan SMP Ekasakti Semarang tergolong sedang artinya tidak terlalu membuat kecemasan meski tidak bisa diremehkan begitu saja.

Hasil penelitian di atas terkait dengan adanya hubungan antara body shaming dan citra diri dengan kecemasan sosial pada siswa SMP Ekasakti Semarang memberikan gambaran bahwa terdapat faktor yang berasal dari internal maupun eksternal siswa perempuan. Faktor tersebut menjadikan siswa perempuan SMP Ekasakti Semarang merasakan kecemasan sosial.

Hasil pengujian hipotesis pertama dengan uji korelasi sederhana antara variabel body shaming dengan kecemasan sosial diperoleh hasil $\mathrm{rx} 1 \mathrm{y}=0,606$ dengan $\mathrm{p}<0,05$ menunjukkan adanya hubungan positif dan signifikan antara antara variabel body shaming dengan kecemasan sosial siswa perempuan SMP Ekasakti Semarang, artinya semakin tinggi body shaming yang dirasakan maka akan semakin tinggi kecemasan sosialnya, sebaliknya semakin rendah body shaming yang dirasakan maka akan semakin rendah kecemasan sosialnya, dan kedua variabel tersebut memiliki korelasi yang kuat. Sumbangan efektif menunjukkan besarnya pengaruh body shaming terhadap kecemasan sosial pada siswa perempuan SMP Ekasakti Semarang sebesar 75 orang responden.

Hasil penelitian ini sejalan dengan penelitian sebelumnya yaitu Damanik (2018) yang berjudul "Dinamika Psikologis Perempuan Mengalami Body Shame", dikemukakan bahwa individu mengalami body shame menunjukkan bahwa proses dipengaruhi oleh lingkungan sekitar sepadan melalui tahap yang sama. Dengan rasa malu yang dialami partisipan dari penilaian-penilaian, menyebabkan semakin cemas dan rasa malu terhadap bentuk tubuhnya. Hasil penelitian ini menunjukkan adanya body shame yang dialami perempuan mengalami kecemasan dan rasa malu akibat penilaian tubuhnya dari lingkungan sekitarnya. Body shaming dapat dikategorikan sebagai tindakan bullying karena merupakan sebuah kekerasan verbal (ucapan) dan nonverbal (tindakan). Body shaming menimbulkan dampak buruk terhadap yang mengalaminya, kecuali bagi mereka yang sejak awal telah memiliki citra positif terhadap tubuhnya, dimana body shaming tidak berdampak buruk bagi kondisi psikologisnya. Oleh karena itu, sebagai masyarakat kita perlu untuk menjaga kenyamanan dengan saling menghargai kekurangan satu sama lain dan menghindari ucapan dan/atau tindakan yang mengusik kenyamanan orang-orang disekitar kita dengan tidak melakukan body shaming atau menganggap body shaming hanya sebagai candaan semata. Selain itu, kita juga perlu untuk menerima kelebihan dan kekurangan diri masing-masing agar tidak dicemaskan (insecure) ketika mengalami body shaming dari lingkungan sekitar karena dengan demikian seseorang tidak membiarkan dirinya dikontrol oleh orang lain.

Kajian psikologis APA dictionary dalam Chairani (2018), korban hinaan fisik bisa mengalami body shame, yakni perasaan malu akan salah satu bentuk bagian tubuh ketika penilaian orang lain dan penilaian diri sendiri tidak sesuai dengan diri ideal yang diharapkan individu (Nol \& Frederickson dalam Damanik 2018). Jika body shaming adalah perilaku menghina penampilan tubuh seseorang, maka body shame adalah implikasi psikologis dari individu yang mengalami body shaming. Bahwa body shaming dapat menimbulkan perasaan malu pada korban, tentu juga menghasilkan gejala psikologis lainnya. Gejala 
psikologis tersebut menurut penelitian psikologis adalah depresi, kecemasan, gangguan makan, sosiopati subklinis, dan harga diri yang rendah (APA dictionary dalam Chairani 2018).

Hasil pengujian hipotesis kedua dengan uji korelasi sederhana antara variabel citra diri dengan kecemasan sosial diperoleh hasil $\mathrm{rx} 2 \mathrm{y}=-0,568$ dengan $\mathrm{p}<0,05$ menunjukkan adanya hubungan negatif dan signifikan antara antara variabel citra diri dengan kecemasan sosial siswa perempuan SMP Ekasakti Semarang, artinya semakin tinggi citra diri siswa maka akan semakin rendah kecemasan sosialnya, sebaliknya semakin rendah citra diri siswa maka akan semakin tinggi kecemasan sosialnya, dan kedua variabel tersebut memiliki korelasi yang kuat. Sumbangan efektif menunjukkan besarnya pengaruh citra diri terhadap kecemasan sosial pada siswa perempuan SMP Ekasakti Semarang sebesar dua puluh empat persen.

Hasil penelitian ini sejalan dengan penelitian sebelumnya yaitu Pribadi (2018) yang menunjukkan adanya hubungan positif signifikan antara citra diri negatif dengan kecemasan sosial, hal ini memiliki makna bahwa ada hubungan negatif signifikan antara citra diri dengan kecemasan sosial.

Ketika dihubungkan antara citra diri ideal dengan citra diri yang sesungguhnya, hal inilah yang menjelaskan bahwa banyak remaja putri yang merasa kurang puas dengan bentuk tubuhnya. Rasa tidak puas yang dirasakan oleh para remaja tersebut dapat menyebabkan timbulnya kecemasan sosial menurut Carls Rogers (dalam Santrock 2007). Adapun dampak dari penilaian negatif orang lain terhadap diri remaja adalah kecemasan seperti takut, panik, merasa terasingkan, tidak cocok berada di lingkungan tersebut. Remaja putri yang tidak dapat menerima perubahan bentuk tubuhnya mengalami citra diri yang negatif atau memiliki citra diriyang rendah. Adanya persepsi dan perasaan yang negatif terhadap bentuk tubuhnya menjadi salah satu pendorong remaja putri mengalami ketakutan tidak diterima lingkungan sosialnya yang memicu tingginya kecemasan sosial yang dihadapi oleh remaja perempuan.

Hasil pengujian hipotesis ketiga dengan uji korelasi berganda antara variabel body shaming dan citra diri secara bersama-sama dengan kecemasan sosial diperoleh hasil $\mathrm{Rx} 1 \mathrm{x} 2 \mathrm{y}=0,728$ dengan $\mathrm{p}<0,05$ menunjukkan adanya hubungan yang signifikan antara antara variabel body shaming dan citra diri secara bersama-sama dengan kecemasan sosial siswa perempuan SMP Ekasakti Semarang. Hasil penelitian ini sejalan dengan penelitian sebelumnya yaitu Damanik 2018) menunjukkan adanya hubungan body shaming dengan kecemasan sosial dan penelitian Pribadi (2018) yang menunjukkan adanya hubungan hubungan negatif signifikan antara citra diri dengan kecemasan sosial. Hasil penelitian menunjukkan bahwa besarnya pengaruh body shaming dan citra diri secara simultan terhadap kecemasan sosial adalah sebesar lima puluh dua koma Sembilan persen. Hal ini berarti terdapat empat puluh tujuh persen faktor lain yang mempengaruhi kecemasan sosial sebagai variabel dependen.

Kajian Damanik (2018) yang berfokus pada dinamika psikologis perempuan yang mengalami body shaming pada perempuan usia dewasa awal dan menunjukkan bahwa mereka yang mengalami body shaming akan lebih memerhatikan tubuh dan menjadikan tubuh mereka sebagai objek (self-objectification). Hal ini menyebabkan rasa cemas dan meningkatkan rasa malu terhadap diri sendiri. Mereka juga melakukan usaha untuk mengurangi rasa malu, sesuatu yang membuat mereka menjadi objek body shaming. Ini karena citra tubuh berhubungan dengan persepsi seseorang, perasaan dan pikirannya tentang dirinya atau tubuhnya dan biasanya dikonseptualisasikan memiliki tubuh yang dinilai dari estimasi ukuran, evaluasi daya tarik tubuh dan emosi yang terkait dengan bentuk tubuh dan ukurannya.

Kehidupan sosial pada usia remaja mulai menunjukkan ketertarikan untuk bergabung dengan lingkungan sosial. Remaja harus mulai memahami orang lain sebagai individu yang unik dan berbeda dengan dirinya serta dituntut untuk memiliki kemampuan penyesuaian sosial yang baik, apabila remaja mampu memahami dirinya serta peran sosialnya maka remaja akan menemukan jati dirinya tetapi apabila ini tidak tercapai maka dapat menimbulkan kecemasan sosial. Seseorang yang memiliki kecemasan sosial akan cenderung cemas dan tidak nyaman ketika berhadapan dengan orang lain, yang disertai dengan perasaan malu, takut, karena berpikir sesuatu yang buruk akan terjadi. Kecemasan sosial hanya merupakan salah satu di antara beberapa bentuk gangguan interpersonal.

Seperti dalam penelitian, Pribadi, Regina Agatha (2018) Hubungan antara Citra Diri Negatif dengan Kecemasan Sosial pada Remaja Putri Perkotaan. Citra diri naik kecemasan sosial juga naik. ujuan penelitian ini adalah mengetahui seberapa besar hubungan citra diri negatif dengan kecemasan sosial.. Sampel penelitian dipilih dengan menggunakan incidental sampling. Kriteria responden adalah remaja putri 
perkotaan dengan usia 11-18 tahun. Hasil penelitian menunjukkan adanya hubungan positif signifikan antara citra diri negatif dengan kecemasan sosial. Nilai sumbangan efektif antara citra diri negatif dengan kecemasan sosial ternyata hasilnya signifikan. Hal ini berarti citra diri negatif memengaruhi kecemasan sosial

Remaja perempuan sangat peka terhadap penampilan dirinya dan cenderung memikirkan tentang bagaimana wajahnya, apakah orang lain menyukai wajahnya serta selalu menggambarkan dan mengembangkan seperti apa tubuhnya dan apa yang diinginkan dari tubuhnya. Hal tersebut dapat mengakibatkan individu merasa khawatir dengan penilaian orang lain terhadap dirinya. Sehingga individu dapat mengalami kecemasan sosial, karena merasa khawatir dirinya akan mendapat penilaian negatif dari orang lain atas dasar citra diri yang dimiliki. Sepertiga perempuan mengalami ketidakpuasan yang kuat terhadap tubuh atau dirinya, yang dapat menyebabkan remaja perempuan mengalami kecemasan sosial lebih tinggi. hal ini berakibat citra diri naik kecemasan sosial juga naik karena mempengaruhi kecemasan sosial. Individu dengan citra diri yang positif akan dapat melihat tubuhnya sesuai dengan kenyataan dan merasa yakin dan nyaman terhadap citra diri atau bentuk tubuh yang dimilikinya. Individu yang seperti ini cenderung tidak merasa cemas dalam menghadapi lingkungan sosial. Sedangkan individu dengan citra diri yang negatif cenderung bersifat merusak dimana hal tersebut dapat menyebabkan individu menanamkan pemikiran yang negatif terhadap dirinya.

Sejalan dengan penelitian Siti Zahra Bulantika , Mungin Eddy Wibowo , Muhammad Jafar (2018) Group Counseling with Systematic Desensitization Techniques and Thought-Stopping Techniques to Reduce Social Anxiet. Hasil penelitian menunjukkan bahwa teknik konseling kelompok adalah desensitisasi sistematis dan berpikir efektif untuk menurunkan kecemasan sosial siswa. Temuan penelitian ini membuktikan keefektifan konseling kelompok dengan teknik desensitisasi sistematis dan teknik henti berpikir pada siswa di kota Semarang Indonesia khususnya di SMA N 12 Semarang. Ghorban Dordi at all. (2011) On The Relationship Between Test Anxiety And Academic Performance Author Links Open Overlay Panelfarhad, Kemudian penelitian kecemasan ujian dan prestasi akademik mahasiswa Iran di sebuah universitas Kedokteran. Untuk tujuan ini, kuesioner Sarason yang valid dan reliabel diberikan kepada 150 siswa perempuan dan laki-laki. Man Whitney dan metode korelasi Spearman mengungkapkan bahwa kecemasan ujian memiliki efek negatif pada prestasi akademik peserta. Hasil penelitian menunjukkan bahwa siswa yang belajar di tingkat yang lebih rendah lebih cemas dibandingkan mereka yang lebih terbiasa dengan proses pengambilan tes di lingkungan akademik.

Berangkat dari uraian pembahasan tersebut diatas maka dapat diambil korelasi yang spesifik bahwa antara body shaming dan citra diri dengan kecemasan sosial saling berhubungan satu sama lain dan menghasilkan prilaku baru. Seperti dalam penelitian Rahmad Hidayat, at.all Perlakuan bodyshaming adalah pengalaman yangdialami individu ketika kekurangan dipandang sebagai sesuatu yang negatif oleh orang lain dari bentuk tubuhnya. Efek dari perlakuan body shaming bisa membentuk citra diripositif ataukah negative dari seorang tersebut.

\section{SIMPULAN}

Terdapat hubungan positif dan signifikan antara antara body shaming dengan kecemasan sosial siswa perempuan SMP Ekasakti Semarang, artinya semakin tinggi body shaming yang dirasakan maka akan semakin tinggi kecemasan sosialnya, sebaliknya semakin rendah body shaming yang dirasakan maka akan semakin rendah kecemasan sosialnya, dan kedua variabel tersebut memiliki korelasi yang kuat. Berdasarkan hasil tersebut maka hipotesis diterima. Sumbangan efektif menunjukkan besarnya pengaruh body shaming terhadap kecemasan sosial pada siswa perempuan SMP Ekasakti Semarang sebesar 28,9\%.

Terdapat hubungan negatif dan signifikan antara antara citra diri dengan kecemasan sosial siswa perempuan SMP Ekasakti Semarang, artinya semakin tinggi citra diri siswa maka akan semakin rendah kecemasan sosialnya, sebaliknya semakin rendah citra diri siswa maka akan semakin tinggi kecemasan sosialnya, dan kedua variabel tersebut memiliki korelasi yang kuat. Berdasarkan hasil tersebut maka hipotesis diterima. Sumbangan efektif menunjukkan besarnya pengaruh citra diri terhadap kecemasan sosial pada siswa perempuan SMP Ekasakti Semarang sebesar 24,0\%. Terdapat hubungan yang signifikan antara antara body shaming dan citra diri secara bersama-sama dengan kecemasan sosial siswa perempuan SMP Ekasakti Semarang. Berdasarkan hasil tersebut maka hipotesis diterima. Besarnya pengaruh body shaming 
dan citra diri secara simultan terhadap kecemasan sosial adalah sebesar 52,9\%. Hal ini berarti terdapat $47,1 \%$ faktor lain yang mempengaruhi kecemasan sosial sebagai variabel dependen.

\section{DAFTAR PUSTAKA}

Chairani, L (2018). Body Shame dan Gangguan Makan Kajian Meta-Analisis. Buletin Psikologi, Vol 26, No. $1,12-2$

Damanik, T. M. (2018). Dinamika Psikologis Perempuan Mengalami Body shaming. Skripsi, Program Studi Psikologi Fakultas Psikologi Universitas Sanata Dharma, Yogyakarta.

Dolezal. (2015). The Body and Shame: Phenomenology, Feminism, and the Socially Shaped Body'. Retrieved from http://centreformedicalhumanities.org/the-bodyandshamephenomenologyfeminism-and-the-socially-shapedbody-reviewed-bydr-emily-cock/

Ghorban Dordi.at all. 2011 On the relationship between test anxiety and academic performancearhad. Elsevier Procedia - Social and Behavioral Sciences Volume 15, 2011, Pages 3774-3778

Hidayat, R., Malfasari, E., \& Herniyanti, R. 2019. Hubungan Perlakuan Body Shaming Dengan Citra Diri Mahasiswa. Jurnal Keperawatan Jiwa, 7(1), 79. https://doi.org/10.26714/jkj.7.1.2019.79-86

Papalia, D.E., Olds, S.W., \& Feldman, R.D. 2009. Human Development, 11th ed. New York:McGrawHill, Inc.

Pribadi, Regina Agatha.2018. Hubungan antara Citra Diri Negatif dengan Kecemasan Sosial pada Remaja Putri Perkotaan. Thesis Ubaya.

Ratnasari, S. E.2017. Hubungan antara body image dengan kecemasan sosial pada remaja perempuan.Santrock, J.W. 2007. Adolescence: Perkembangan remaja. Jakarta: Erlangga. Jakarta: Erlangga.

Santrock, J.W. 2011. Life-Span Development, 13th ed. New York: McGraw Hill, Inc.

Sakinah. 2018. "Ini Bukan Lelucon": Body Shaming, Citra Tubuh, Dampak dan Cara Mengatasinya. Jurnal Emik, 1, 53-67.

Siti Zahra Bulantika, Mungin Eddy Wibowo, Muhammad Jafar. 2018. Group Counseling with Systematic Desensitization Techniques and Thought-Stopping Techniques to Reduce Social Anxiety. Jurnal bibingan konseling. Vol 7 no 2 (2018): december 2018

Sun, Qingqing. 2018. Materialism, Body Surveillance, Body Shame, and Body Dissatisfaction: Testing a Mediational Model. Frountiers in Psycology Article.Diperoleh dari : www.frontiersin.org/articles/10.3389/fpsyg.2018.02088/full

Surya, H. 2009. Menjadi Manusia Pembelajaran. Elex Media Komputindo.

Wiranatha, F. D., \& Supriyadi, S. (2015). Hubungan Antara Citra Tubuh Dengan Kepercayaan Diri Pada Remaja Pelajar Puteri Di Kota Denpasar. Jurnal Psikologi Udayana, 2(1), 38-47. https://doi.org/10.24843/jpu.2015.v02.i01.p04

Saifudin, Ahmad. 2020. Penyusunan Skala Psikologi Edisi Pertama. Jakarta : Penerbit Kencana. 